\title{
ANALISIS KEBIJAKAN PERUSAHAAN DAN \\ PARTISIPASI TENAGA KERJA PADA BAGIAN PRODUKSI TERHADAP PENERAPAN 5R PT. MARITIM BARITO PERKASA
}

\author{
Ghandy Elmada Setyanto \\ Ikatan Alumni Kesehatan Masyarakat Indonesia (IAKMI) Provinsi Jawa Timur \\ E-mail: ghandyelmada10@gmail.com
}

\begin{abstract}
$5 R$ is a program to minimize or eliminate the danger by treating a workplace correctly. A good work and comfortable environment should be arranged so that workers can work without distractions. A good housekeeping will being held if the workers participate and obey all rules in the company not only just participate, but also contribute management of the company for $5 R$ implementation. This study aims to analyze company's policy dan participate of workers on sector production with $5 R$ implementation in PT. Maritim Barito Perkasa Banjarmasin. This study used a cross-sectional design. Research on samples used 20 samples who are all of worker in sector production. The result of the research showed that $5 R$ policy of PT. Maritim Barito Perkasa has not written. The knowledge level of workers were mostly understand about $5 R$ implementation of PT. Maritim Barito Perkasa. And attitude that shown by workers about 5R implementation also good. Underliner of this research can be suggested to company is to make a written policy about $5 R$ implementation. Forming audit team can be conducted every 3 month to help applying $5 R$ implementation. $5 R$ implementation must be supported from every side so that problem about $5 R$ implementation can be realized maximally and continously.
\end{abstract}

Keywords: worker's participation, company policy, 5R implementation

\section{ABSTRAK}

Program 5R merupakan usaha untuk meminimalisir atau menghilangkan bahaya dengan budaya memperlakukan tempat kerja secara benar. Lingkungan kerja yang baik dan nyaman harus dapat diusahakan agar para pekerja dapat melakukan pekerjaan tanpa mengalami gangguan. Ketatarumahtanggaan yang baik akan terselenggara jika tenaga kerja berpartisipasi dan mematuhi seluruh peraturan yang ada bukan hanya partisipasi tetapi juga andil pimpinan perusahaan dalam usaha menerapkan program 5R. Studi ini bertujuan menganalisis kebijakan perusahaan dan partisipasi tenaga kerja bagian produksi terhadap penerapan 5R di PT. Maritim Barito Perkasa Banjarmasin. Studi ini menggunakan desain crosssectional. Sampel pada penelitian ini menggunakan total populasi yaitu dengan populasi 20 orang. Hasil penelitian menunjukkan bahwa kebijakan yang ada di PT. Maritim Barito Perkasa tentang 5R belum dibuat secara tertulis. Tingkat pengetahuan tenaga kerja sebagian besar paham tentang penerapan 5R yang ada di PT. Maritim Barito Perkasa. Dan sikap yang ditunjukkan oleh tenaga kerja tentang penerapan $5 \mathrm{R}$ juga sebagian besar adalah baik. Berdasarkan hasil penelitian ini saran yang dapat diberikan adalah membuat kebijakan tertulis tentang 5R. Pembentukan dengan melakukan tim audit dapat dilakukan setiap 3 bulan sekali guna membantu penerapan 5R. Karena dukungan bukan hanya dari salah satu pihak saja tetapi dari semua pihak agar program $5 \mathrm{R}$ bisa terwujud secara maksimal dan terus menerus

Kata kunci: partisipasi tenaga kerja, kebijakan perusahaan, penerapan 5R

\section{PENDAHULUAN}

Kesehatan dan Keselamatan Kerja merupakan salah satu persyaratan untuk meningkatkan produktivitas tenaga kerja dan merupakan hak asasi setiap tenaga kerja. Dan, untuk memenangkan persaingan pasar bebas ternyata kesehatan dan keselamatan kerja juga menjadi salah satu persyaratan yang harus dipenuhi oleh industry di Indonesia (Sutjana, 2006). Di era globalisasi ini, perkembangan berbagai macam teknologi yang canggih sangat sering kita jumpai dan menjadi bagian penting dalam sebuah perusahaan. Dengan adanya teknologi yang canggih, maka nantinya perusahaan akan memperoleh hasil-hasil produksi yang cepat dan konsisten.

Tetapi, di sisi lain pada dasarnya teknologi juga dapat menjadi ancaman bagi manusia apabila tidak digunakan dan dijalankan sebagaimana mestinya. Keterampilan manusia juga harus diperhitungkan dalam mengendalikan mesin yang berat dan ringan agar kecelakaan kerja dapat terminimalisir.

Dari data yang dikeluarkan Jamsostek pada tahun 2012, kecelakaan kerja menembus angka 103.000 jiwa dengan rata-rata kecelakaan kerja 
setiap harinya adalah 9 orang. Pada tahun 2013, tingkat kecelakaan kerja bertambah menjadi 129.911 orang dan pada tahun 2014 data yang dikeluarkan oleh Jamsostek menurun menjadi 105.383 orang yang mengklaim kecelakaan kerja. Dari data tersebut bisa menjelaskan bahwa pentingnya Kesehatan dan Keselamatan Kerja dalam berbagai perusahaan.

Lingkungan kerja yang baik dan nyaman harus dapat diusahakan agar para pekerja dapat melakukan pekerjaan tanpa mengalami gangguan. Rasa semangat dari para pekerja juga dapat timbul dari lingkungan kerja yang indah, nyaman, kondusif, dan penataan tempat kerja yang baik. Karena nantinya hal tersebut akan berdampak langsung dengan hasil produksi dan perkembangan perusahaan.

Kebijakan dari perusahaan terkait penerapan $5 \mathrm{R}$ harus dibuat karena untuk menciptakan sebuah perusahaan yang baik, sikap yang baik harus dimulai dari pihak yang penting dalam perusahaan sehingga pihak yang di bawah dan seterusnya juga akan mengikuti. Jika dalam penerapannya hanya dilakukan dari pihak manajemen tanpa adanya keikutsertaan dari tenaga kerja maka penerapan 5R tersebut tidak akan berjalan maksimal dan akan menambah masalah internal perusahaan. Dengan memahami karakter masing-masing anak buah, seorang pimpinan akan mampu berkomunikasi, sehingga tenaga kerja tidak seperti diperintah melainkan juga merasa memiliki perusahaan tersebut dan berusaha bekerja untuk mencapai tujuan perusahaan (Sijangga, 2009).

Untuk menciptakan lingkungan yang bersih, rapi, aman dan nyaman sesuai Peraturan Menteri Perburuhan Nomor 7 Tahun 1964, maka pemeliharaan ketatarumahtanggan (housekeeping) yang baik perlu diterapkan di tempat kerja. Salah satu usaha untuk menerapkan housekeeping yang baik adalah penerapan program 5R (Ringkas, Rapi, Resik, Rawat, dan Rajin) di tempat kerja.

Housekeeping atau 5R ini diharapkan berkesinambungan dan sustainable. Dibutuhkan pemantauan terus menerus. 5R bukan hanya sekedar mengimprovisasi lingkungan kerja tetapi menanamkan sikap dan perilaku tenaga kerja yaitu kedisiplinan dan kepatuhan dalam bekerja. Program 5R merupakan salah satu pencegahan kecelakaan kerja. Melalui 5R tenaga kerja diberi petunjuk yang jelas bagaimana proses menjadi tanggung jawab masing-masing, kemudian melaksanakan tanggung jawab itu sebaik mungkin setiap hari.

Bagian Produksi di PT. Maritim Barito Perkasa yang dalam prosesnya menggunakan teknologi canggih yang tidak terlepas dari risiko bahaya kecelakaan kerja. Ada berbagai jenis mesin yang digunakan di bagian produksi di PT Maritim Barito Perkasa.

Sebagian besar tenaga kerja berhubungan dengan mesin-mesin dan peralatan yang merupakan faktor bahaya kecelakaan kerja. Tidak menutup kemungkinan juga bahwa mesin-mesin itu sendiri yang membuat bahaya kecelakaan kerja.

Partisipasi dari tenaga kerja pada bagian produksi harus diwujudkan semaksimal mungkin agar hal-hal yang bersifat kecerobohan, keteledoran dapat diminimalisir sebaik mungkin sehingga tercipta suasana tempat kerja yang rapi dan nyaman karena kondisi tempat kerja mencerminkan perilaku seseorang terhadap pekerjaannya dan perlakuan terhadap pekerjaan mencerminkan sikapnya terhadap pekerjaan itu sendiri (Hirano, 1995).

Penelitian ini bertujuan untuk menganalisis kebijakan perusahaan dan partisipasi tenaga kerja bagian produksi terhadap penerapan 5R di PT. Maritim Barito Perkasa Banjarmasin.

\section{METODE}

Penelitian ini merupakan penelitian observasional dan bersifat deskriptif dengan cara menggambarkan suatu keadaan tertentu yaitu dengan berinteraksi pada responden dengan kuesioner dan indepth interview kepada pihak perusahaan. Setelah itu akan diolah data yang sudah secara tekstular. Dari segi waktu, penelitian ini bersifat crosssectional karena penelitian ini dilakukan secara serentak dalam satu waktu tertentu (Notoatmodjo, 2012).

Populasi dalam penelitian ini adalah seluruh tenaga kerja pada bagian produksi yang berjumlah 20 orang. Informan pada penelitian ini memiliki kesediaan berpartisipasi dengan menandatangani lembar persetujuan. Penelitian ini dilaksanakan di bagian produksi PT. Maritim Barito Perkasa Banjarmasin pada tanggal 21 Juli sampai 10 Oktober 2015.

Lokasi penelitian pada PT. Maritim Barito Perkasa adalah Jl. Tembus Pelabuhan Martapura Baru No.25. RT.26. Mantuil, Banjarmasin 70245, Kalimantan Selatan.

Variabel dalam penelitian ini meliputi tingkat pengetahuan tenaga kerja, Distribusi tenaga kerja menurut sikap terhadap penerapan Ringkas, Penerapan Rapi, Penerapan Resik, Penerapan, Rawat, dan Penerapan Rajin. 
Komponen penelitian ini dihimpun melalui kuesioner. Setelah pengambilan data maka akan dilakukan pengolahan data secara tekstular kemudian dilakukan secara deskriptif, antara lain membandingkan data yang diperoleh dengan standar yang ada sehingga diperoleh hasil dan gambaran yang jelas seperti tujuan diatas serta dapat ditarik suatu kesimpulan.

\section{HASIL}

\section{Gambaran Umum Tempat Penelitian}

PT Maritim Barito Perkasa telah menjadi kontraktor utama Adaro Indonesia sejak tahun 2009 yang menyediakan armada modern kapal tunda, tongkang dan tongkang berbaling-baling dari Kelanis ke pelabuhan lepas pantai Taboneo dan ke Terminal IBT untuk menyediakan fasilitas pemuatan kapal dan pengiriman langsung ke pelanggan domestik di Pulau Jawa. MBP merupakan kontraktor pemuatan kapal terbesar dengan armada kapal tunda yang besar dan modern.

Orchard Maritime Logistics Pte. Ltd. (OML) adalah perusahaan tongkang dan pemuatan kapal yang berbasis di Singapore dan yang 95\% kepemilikannya dimiliki oleh Adaro Energy, tetapi sebagian besar aset OML direstrukturisasi menjadi PT Maritim Barito Perkasa ("MBP") dan PT Harapan Bahtera Internusa ("HBI") sejak Oktober 2009.

Hal ini dilakukan untuk memenuhi peraturan menteri transportasi tahun 2005 mengenai pelaksanaan hukum cabotage yang menyatakan bahwa transportasi barang dengan kapal di sepanjang pantai pelabuhan domestik harus dilakukan oleh operator pelayaran domestik dengan membawa sebuah bendera Indonesia.

MBP dan HBI adalah perusahaan pelayaran nasional dengan lisensi dalam negeri, yang diakusisi dengan jumlah nominal pada semester kedua tahun 2009 oleh Adaro Energy. MBP menangani jasa tongkang domestik untuk Adaro Indonesia, sementara HBI menangani jasa tongkang pihak ketiga di Indonesia.

Seluruh armada di bawah bendera Indonesia pada awal tahun 2010. Pergantian ke registrasi Indonesia dapat dilakukan tanpa gangguan terhadap daya dukung armada dan kewajiban pengiriman tonase kepada Adaro dan pelanggan lainnya.

OML sekarang menangani pelanggan di luar Indonesia, memberikan dukungan logistik dan memegang portofolio untuk perencanaan ekspansi armada, pembelian dan konstruksi baru pada kapal untuk MBP dan HBI.

Visi dari perusahaan adalah to be the most efficient barging and trans-shipment company yang berarti untuk menjadikan tongkang dan jasa pengiriman perusahaan yang paling efisien.

Misi dari PT. Maritim Barito Perkasa ada 2 yakni Providing efficient barging and trans-shipment services mainly for Adaro Group yang berarti memberikan pelayanan terutama berupa tongkang dan jasa pengiriman perusahaan yang efisien untuk Grup Adaro dan yang kedua adalah Ensuring high quality safety standard and environmentally sound barging and trans-shipment operations yang berarti menjamin standar kualitas keselamatan yang tinggi dan tongkang yang baik bagi lingkungan dan operasi jasa pengiriman.

Produksi di PT Maritim Barito Perkasa pada umumnya bergerak pada bidang shipping company yaitu menyediakan armada kapal untuk Adaro. Untuk rute pelayarannya adalah dari kelanis sampai dengan taboneo. Untuk produksi pada area workshop yang memiliki sub bagian yakni bagian welding, mechanic, dan eletrican terdapat berbagai macam produksi diantaranya yaitu, membantu performa dari armada kapal agar tetap terjaga dengan cara membuat benda yang dibutuhkan oleh kapal itu sendiri. Misalnya yaitu membuat plat, memperbaiki mesin, membuat tambalan kapal dan masih banyak lainnya.

\section{Kebijakan Pimpinan Perusahaan dalam Pelaksanaan 5R di PT. Maritim Barito Perkasa}

Kebijakan dalam pelaksanaan program $5 \mathrm{R}$ di PT. Maritim Barito Perkasa belum tertulis dan belum menyeluruh hanya pada bagian office saja. Tenaga kerja mempunyai tanggung jawab menjaga tempat kerjanya dan ikut berpartisipasi dalam program $5 R$.

Penerapan 5R yang diterapkan oleh perusahaan mulai terbentuk sejak awal 2015 dan terbentuknya mulai dari perlombaan tentang $5 \mathrm{R}$ pada bagian office atau bagian administrasi saja

Selain itu, belum terbentuknya pengurus $5 \mathrm{R}$ dan tim audit tentang $5 \mathrm{R}$ yang membuat penerapan $5 \mathrm{R}$ belum bisa dijalankan. Maka evaluasi penerapan 5R yang seharusnya bisa diterapkan untuk menunjang kemajuan perusahaan belum bisa diterapkan. Seharusnya, dalam penerapan tentang $5 \mathrm{R}$ yang bak perlu adanya struktur yang baik seperti organisasi pengurus dan tim audit agar dapat berjalan maksimal. 
Tempat kerja yang indah dan nyaman menjadi sebuah idaman bagi para tenaga kerja. 5R ikut andil dalam membangun keunggulan kompetitif perusahaan, maka tenaga kerja diharapkan mampu memanfaatkan seluruh peluang yang ada sebagai inovasi penyelesaian masalah tiap unit kerja pada perusahaan.

Dalam pelaksanaannya, 5R pada PT. Maritim Barito Perkasa masih melalui tahap awal dan pembentukan. Itu menjelaskan bahwa masih terdapat aspek-aspek yang perlu dibenahi seperti pelaksanaan Ringkas, Rapi, dan lain sebagainya. Seperti halnya di office, masih terdapat tumpukan-tumpukan kertas yang berada di atas meja, kemudian masih belum terdapatnya $5 \mathrm{R}$ pada bagian produksi.

\section{Tingkat Pengetahuan Tenaga Kerja Terhadap Program 5R}

Untuk mengetahui tingkat pengetahuan dari tenaga kerja maka dilakukan penyebaran kuesioner yang dilakukan melalui pendekatan kualitatif. Lembar kuesioner tersebut telah diberi nilai untuk mengetahui jumlah total pada semua pertanyaan dari masing-masing tenaga kerja, yang dikelompokkan pada tabel ini

Tabel 1. Distribusi Tenaga Kerja Menurut Tingkat Pengetahuan di Bagian Produksi PT. Maritim Barito Perkasa 2015

\begin{tabular}{lrr}
\hline Tingkat Pengetahuan 5R & N & \% \\
\hline Kurang & 0 & 0 \\
Cukup & 2 & 10 \\
Baik & 18 & 90 \\
\hline Total & 20 & 100 \\
\hline
\end{tabular}

Pada gambaran distribusi tersebut terlihat tingkat pengetahuan pada tenaga kerja di bagian produksi PT. Maritim Barito Perkasa sudah baik. Dari 20 orang tenaga kerja ada 18 orang tenaga kerja dari hasil penelitian yang tingkat pengetahuan tentang $5 \mathrm{R}$ yang baik. Sedangkan yang lainnya adalah cukup. Ini membuktikan bahwa tingkat pengetahuan tenaga kerja yang berada pada bagian produksi sudah baik dengan persentase $90 \%$.

\section{Sikap Tenaga Kerja pada penerapan Ringkas di bagian Produksi PT. Maritim Barito Perkasa}

Untuk mengetahui sikap tenaga kerja terhadap program 5R dari tenaga kerja maka dilakukan penyebaran kuesioner yang dilakukan melalui pendekatan kualitatif. Pendekatan Kualitatif adalah pendekatan yang berusaha mengungkapkan berbagai keunikan yang terdapat individu, kelompok, masyarakat, dan organisasi dalam kehidupan sehari-hari secara menyeluruh, rinci, dan dapat dipertanggungjawabkan secara ilmiah.

Dalam hal ini sikap yang akan digambarkan dalam bentuk tabel adalah terhadap penerapan ringkas yaitu dengan pertanyaan bagaimana jika menemukan barang yang tidak diperlukan. Berdasarkan distribusi tenaga kerja menurut sikap terhadap penerapan Ringkas di PT Maritim Barito Perkasa, frekuensi paling sering dilakukan oleh tenaga kerja dalam hal penerapan ringkas adalah Memilah dan membuang barang yang tidak diperlukan ke tempat sampah sebanyak 12 orang.

Kemudian yang pilihan lainnya yang sering dilakukan oleh tenaga kerja pada bagian produksi adalah membuang sampah ke tempat sampah dengan jumlah tenaga kerja sebanyak 8 orang atau persentase sebesar 40\%. Selain itu Terlihat masih banyak mesin/ peralatan yang rusak berada di lingkungan kerja bagian produksi. Barang yang tidak terpakai masih ada di area kerja. Seharusnya, untuk peralatan/ mesin kerja yang tidak terpakai seharusnya diidentifikasi dan memilahnya apakah ingin diperbaiki atau dibuang sehingga tidak mengganggu tenaga kerja untuk bekerja setiap harinya.

Pada tempat pakaian kerja (locker) masih terdapat pakaian kerja yang bergelantungan di luar locker pakaian. Hal ini membuat pandangan menjadi tidak nyaman.

Padahal, ukuran locker cukup untuk memasukkan pakaian kerja. Ditambah dengan ruang istirahat yang sempit membuat akses gerak tenaga kerja menjadi sedikit. Sebaiknya ada tempat tersendiri untuk menggantungkan pakaian kerja

Tabel 2. Distribusi Tenaga Kerja Menurut Sikap Terhadap Penerapan Ringkas (Jika Menemukan Barang Tidak diperlukan) di Bagian Produksi PT. Maritim Barito Perkasa 2015

\begin{tabular}{lrc}
\hline \multicolumn{1}{c}{ Sikap } & N & \% \\
\hline Tidak ada yang bisa dilakukan dengan & 0 & 0 \\
barang tersebut & & \\
Membuang barang ke tempat sampah & 8 & 40 \\
Memilah dan membuang barang yang & 12 & 60 \\
tidak diperlukan ke tempat sampah & & \\
\hline Total & 20 & 100 \\
\hline
\end{tabular}

Dalam hal ini bagian memilah dan membuang barang yang tidak diperlukan merupakan sikap yang benar di antara ketiga sikap diatas. Karena 
dengan memilah barang kita akan tahu mana yang akan dibuang. Jika hanya membuang sampah tanpa adanya pemilahan, akan memperlambat proses pembuangan dan proses daur ulang. ha

\section{Sikap Tenaga Kerja pada Penerapan Rapi di bagian Produksi PT. Maritim Barito Perkasa}

Distribusi yang kedua adalah sikap terhadap penerapan rapi yang dilakukan oleh tenaga kerja pada bagian produksi. Pertanyaan yang diberikan dalam bentuk kuesioner kepada tenaga kerja adalah bagaimana sikap setelah menggunakan peralatan kerja.

Berikut distribusi tenaga kerja menurut sikap terhadap penerapan Rapi di PT Maritim Barito Perkasa, berdasarkan dari ketiga sikap di atas, sikap yang menunjukkan rapi adalah berusaha selalu merapikan peralatan di tempat penyimpanan.

Tabel 3. Distribusi Tenaga Kerja Menurut Sikap terhadap Penerapan Rapi (Setelah Menggunakan Peralatan Kerja) di Bagian Produksi PT. Maritim Barito Perkasa 2015.

\begin{tabular}{lrr}
\hline \multicolumn{1}{c}{ Sikap } & N & \multicolumn{1}{c}{$\%$} \\
\hline Tidak ada peralatan yang perlu disimpan & 1 & 5 \\
$\begin{array}{l}\text { Menyimpan peralatan di tempat } \\
\text { penyimpanan }\end{array}$ & 10 & 50 \\
$\begin{array}{l}\text { Berusaha selalu merapikan peralatan di } \\
\text { tempat penyimpanan }\end{array}$ & 9 & 45 \\
Total & 20 & 100 \\
\hline
\end{tabular}

Karena jika hanya menyimpan peralatan tanpa merapikan di tempat penyimpanan akan membuat tenaga kerja kesulitan untuk mencari alat kerja dikemudian hari dan yang terjadi adalah waktu yang terbuang percuma dan produktivitas yang menurun juga

Begitu juga bila tidak ada peralatan yang disimpan maka penerapan rapi dapat dikatakan belum diterapkan dalam area kerja. Hasilnya dari penerapan rapi pada bagian produksi PT. Maritim Barito Perkasa frekuensi paling sering dilakukan adalah Menyimpan peralatan di tempat penyimpanan sebanyak 10 orang atau dengan persentase sebesar $50 \%$.

\section{Sikap Tenaga Kerja pada penerapan Resik di bagian Produksi PT. Maritim Barito Perkasa}

Distribusi yang ketiga adalah sikap terhadap penerapan resik yang dilakukan oleh tenaga kerja pada bagian produksi. Pertanyaan yang diberikan dalam bentuk kuesioner kepada tenaga kerja adalah bagaimana perlakuan ketika terdapat kotoran di tempat kerja.

Tabel 4. Distribusi Tenaga Kerja Menurut Sikap terhadap Penerapan Resik (Jika Terdapat Kotoran di Tempat Kerja) di Bagian Produksi PT. Maritim Barito Perkasa 2015.

\begin{tabular}{lrr}
\hline \multicolumn{1}{c}{ Sikap } & N & \multicolumn{1}{c}{$\%$} \\
\hline Tidak melakukan apa-apa & 1 & 5 \\
Menunggu petugas kebersihan & 3 & 15 \\
membersihkan & & \\
Langsung membersihkan kotoran tersebut & 16 & 80 \\
\hline Total & 20 & 100 \\
\hline
\end{tabular}

Berdasarkan distribusi tenaga kerja menurut sikap terhadap penerapan Resik di PT Maritim Barito Perkasa. Frekuensi paling sering dilakukan adalah Langsung membersihkan kotoran tersebut sebanyak 16 orang $(80 \%)$. Dalam hal penerapan resik, dari ketiga sikap di atas pernyataan yang paling benar adalah langsung membersihkan kotoran tersebut. Karena dengan langsung membersihkan tanpa ada paksaan dari pihak manapun maupun menunggu petugas kebersihan, berarti tenaga kerja sudah ikut ambil bagian dalam hal penerapan $5 \mathrm{R}$ pada area kerja.

\section{Sikap Tenaga Kerja pada Penerapan Rawat di bagian Produksi PT. Maritim Barito Perkasa}

Distribusi yang keempat adalah sikap terhadap penerapan rawat yang dilakukan oleh tenaga kerja pada bagian produksi. Pertanyaan yang diberikan dalam bentuk kuesioner kepada tenaga kerja adalah bagaimana perlakuan terhadap kondisi peralatan di tempat kerja.

Tabel 5. Distribusi Tenaga Kerja Menurut Sikap terhadap Penerapan Rawat (Kondisi Peralatan Tempat Kerja) di Bagian Produksi PT. Maritim Barito Perkasa 2015.

\begin{tabular}{lrr}
\hline \multicolumn{1}{c}{ Sikap } & N & \% \\
\hline $\begin{array}{l}\text { Membiarkan karena besok di akan } \\
\text { dipakai lagi }\end{array}$ & 0 & 0 \\
$\begin{array}{l}\text { Langsung menyimpan di tempat } \\
\text { penyimpanan }\end{array}$ & 7 & 35 \\
$\begin{array}{l}\text { Mempertahankan agar kondisi peralatan } \\
\text { kerja tetap bersih dan tidak rusak }\end{array}$ & 13 & 65 \\
Total & 20 & 100 \\
\hline
\end{tabular}


Berdasarkan distribusi tenaga kerja menurut sikap terhadap penerapan Rawat di PT Maritim Barito Perkasa, frekuensi paling sering dilakukan adalah Mempertahankan agar kondisi peralatan kerja tetap bersih dan tidak rusak sebanyak 13 orang (65\%). Dan yang langsung menyimpan di tempat penyimpanan sebanyak 7 orang.

Dalam hal ini mempertahankan agar kondisi peralatan kerja tetap bersih dan tidak rusak merupakan penerapan yang benar di antara ketiga sikap di atas. Jika langsung menyimpan peralatan kerja tanpa merawat dan membersihkannya maka yang terjadi peralatan akan cepat rusak dan biaya tambahan produksi akan menjadi semakin bertambah.

\section{Sikap Tenaga Kerja pada penerapan Rajin di bagian Produksi PT. Maritim Barito Perkasa}

Distribusi dari Pertanyaan yang diberikan dalam bentuk kuesioner kepada tenaga kerja adalah bagaimana ketepatan waktu datang para tenaga kerja bagian produksi.

Tabel 6. Distribusi Tenaga Kerja Menurut Sikap terhadap Penerapan Rajin (Ketepatan Waktu Saat Datang) di Bagian Produksi PT. Maritim Barito Perkasa 2015.

\begin{tabular}{lrr}
\hline \multicolumn{1}{c}{ Sikap } & N & \multicolumn{1}{c}{$\%$} \\
\hline Tidak Pernah & 0 & 0 \\
Kadang-kadang & 2 & 10 \\
Selalu & 18 & 90 \\
\hline Total & 20 & 100 \\
\hline
\end{tabular}

Berdasarkan distribusi tenaga kerja menurut sikap terhadap penerapan Rajin, frekuensi paling sering dilakukan adalah selalu tepat waktu sebanyak 18 orang $(90 \%)$. Ketepatan waktu saat datang sangat diperlukan oleh perusahaan untuk menciptakan suasana yang disiplin. Dengan ketepatan waktu pada saat datang, berarti tenaga kerja sudah membantu perusahaan untuk ikut andil dalam pertumbuhan produksi dan perkembangan perusahaan.

\section{PEMBAHASAN}

\section{Kebijakan Pimpinan Perusahaan dalam Pelaksanaan 5R di PT. Maritim Barito Perkasa}

5R di dalam perusahaan ini baru diperkenalkan pada awal tahun 2015 yaitu sekitar 9 bulan yang lalu. Dalam memperkenalkan penerapan 5R, maka departemen $H S E Q$ membuat inisiatif yaitu membuat lomba pada saat adanya bulan K3.Dalam pelaksanaannya, penerapan $5 \mathrm{R}$ ini belum sama sekali berkelanjutan. Di bagian office, masih banyak terlihat tumpukan kertas yang tidak tertata rapi. Dan $5 \mathrm{R}$ hanya dibuat untuk ajang lomba setiap tahun sekali.

Kebijakan yang belum tertulis dari pimpinan perusahaan tentang $5 \mathrm{R}$ juga membuat perusahaan yang bergerak di bidang transportasi batu bara ini kesulitan untuk menerapkan program yang berkaitan $5 \mathrm{R}$ pada semua bagian atau unit yang ada di perusahaan tersebut. Tetapi kegiatan yang berkaitan dengan 5R seperti melakukan pembersihan area kerja, merawat area dan peralatan, dan sifat rajin sudah diterapkan oleh para tenaga kerja.

Menurut Sukmawati (2005), dukungan pimpinan perusahaan sangat diperlukan dalam pelaksanaan $5 R$, tanpa dukungan pimpinan pelaksanaan $5 \mathrm{R}$ akan sulit berhasil. Teladan sangat penting dan berpengaruh pada tenaga kerja, pimpinan yang meninjau ke area kerja akan menjadi pemacu semangat bagi seluruh tenaga kerja

Contoh kebijakan yang dibuat oleh pihak manajemen perusahaan kepada seluruh tenaga kerja agar dapat menerapkan program 5R secara maksimal adalah membuat pernyataan langsung yang ditulis agar para tenaga kerja patuh terhadap pernyataan tersebut. Yang kedua adalah dengan membuat tim audit dan tim implementasi $5 \mathrm{R}$ sesuai tugas dan tanggung jawab masing-masing.

Pengecekan oleh tim audit bisa dilakukan setiap 3 bulan sekali atau sesuai dengan kebijakan perusahaan masing-masing. Nantinya jika pada audit pada temuan sebelumnya belum ada perbaikan maka hambatan-hambatan selama audit harus dibahas pada pertemuan $5 \mathrm{R}$ yang melibatkan pimpinan yang ada di unit kerja yang di audit. Kemudian dari pertemuan tersebut dibahas secara bersama dan menentukan solusi apa yang tepat untuk penanganan hambatan tersebut. Kegiatan tersebut di atas mengikuti siklus plan-do-check-action.

Oleh karena itu perlu adanya kebijakan tertulis dari pihak pimpinan tentang $5 \mathrm{R}$ dan partisipasi dari seluruh tenaga kerja dalam perusahaan agar sesuai dengan peraturan Undang-undang no 1 Tahun 1970 tentang keselamatan Kerja Bab III pasal 3 ayat 1 huruf D dan Peraturan Menteri Perburuhan no. 7 Tahun 1964 tentang Syarat Kesehatan, Kebersihan serta Penerangan Dalam Tempat Kerja. Untuk penerapan di area kerja diperlukan Surat Keterangan pimpinan sebagai perwujudan kebijakan pimpinan perusahaan. 


\section{Tingkat Pengetahuan Tenaga Kerja terhadap Program 5R}

Menurut Notoatmodjo (2012), pengetahuan merupakan hasil "tahu" dan ini terjadi setelah orang mengadakan penginderaan terhadap suatu objek tertentu. Penginderaan terhadap objek terjadi melalui panca indera manusia yaitu penglihatan, pendengaran, penciuman, rasa dan raba dengan sendiri. Pada waktu pengindraan sampai menghasilkan pengetahuan tersebut sangat dipengaruhi oleh intensitas perhatian persepsi terhadap objek.

Partisipasi tenaga kerja dalam penerapan 5R sangat dibutuhkan oleh perusahaan untuk memperoleh kinerja yang maksimal, lingkungan yang aman, dan produktivitas yang meningkat. Dengan tenaga kerja berpartisipasi terhadap penerapan $5 \mathrm{R}$, tenaga kerja sudah ikut membantu perusahaan untuk selangkah lebih maju dalam persaingan yang global ini.

Salah satu bentuk partisipasi yang dapat dilakukan oleh tenaga kerja adalah tingkat pengetahuan tentang penerapan 5R. Tingkat pengetahuan yang dimaksud adalah pengetahuan mengenai bagaimana penerapan 5R seperti menjaga lingkungan kerja, bagaimana merawat peralatan kerja, apa saja yang dilakukan ketika melihat barangbarang atau alat-alat yang berserakan di area kerja dan lain sebagainya.

Dalam tingkat pengetahuan, tenaga kerja di bagian produksi sudah baik hal itu dibuktikan dengan dari 20 orang yang bekerja di dalam area produksi ada 18 orang yang tingkat pengetahuannya baik.

Dua orang tenaga kerja lainnya adalah cukup. Pendidikan dan penyuluhan tentang 5R pada bagian produksi di PT. Maritim Barito Perkasa belum pernah diberikan oleh supervisor kepada seluruh tenaga kerja lama maupun baru. Sebaiknya dari pihak supervisor pada bagian produksi untuk memberikan penyuluhan terkait penerapan $5 \mathrm{R}$ dan bagaimana cara penanganannya. Hal ini sangat perlu agar penerapan yang dilakukan oleh tenaga kerja pada bagian produksi dapat berjalan secara maksimal dan tidak hanya sekedar paham saja.

Ketatarumahtanggaan yang baik akan terselenggara jika tenaga kerja berpartisipasi dan mematuhi seluruh peraturan yang ada, seperti: tidak meletakkan barang pada jalan lalu lintas atau penggunaan tempat sampah untuk pembuangan kotoran. Sekali kebiasaan baik tertanam, penghayatan selanjutnya adalah lebih mudah karena keteraturan selain bermanfaat bagi keselamatan kerja juga banyak faedahnya untuk kelancaran pekerjaan. Dalam menciptakan kondisi lingkungan kerja yang teratur dan nyaman diwujudkan dengan penerapan 5R yang baik (Suma'mur, 1997).

\section{Sikap Tenaga Kerja pada Penerapan Ringkas di bagian Produksi PT. Maritim Barito Perkasa}

Hasil penelitian pada Tabel 2 telah digambarkan bahwa kebanyakan tenaga kerja mempunyai sikap pada pernyataan memilah dan membuang barang yang tidak diperlukan ke tempat sampah sebanyak 12 orang. Kegiatan ini memang haruslah dilakukan oleh tenaga kerja agar proses aktivitas kerja tidak terhambat. Dengan tenaga kerja memilah barang terlebih dahulu sebelum membuang maka tenaga kerja menjadi semakin paham akan penerapan ringkas.

Ringkas adalah menyingkirkan barang yang tidak diperlukan dan memastikan bahwa barang yang diperlukan disimpan dengan benar dan dalam jangkauan supaya lebih efisien. Tempat kerja harus bebas dari semua benda yang tidak diperlukan di tempat kerja. Tempat kerja harus ringkas karena jika tidak akan menghambat produktivitas kerja dan menimbulkan bahaya kecelakaan (Jahja, 2009).

8 orang tenaga kerja yang lainnya lebih memilih hanya membuang barang ke tempat sampah. Ini membuktikan bahwa masih ada tenaga kerja yang belum tahu penerapan ringkas secara benar. Perlu adanya arahan dari atasan atau kebijakan tertulis dari pimpinan. Ringkas merupakan langkah awal dari 5R dan merupakan langkah yang sangat strategis. Tenaga kerja menanggung beban mental dalam bekerja sehingga unjuk kerjanya terpengaruh. Bila kecelakaan terjadi, semua pihak merasa dirugikan. Perusahaan mengalami penurunan produktivitas karena penurunan semangat kerja. Tenaga kerja pada dasarnya ingin bekerja dengan baik, bukan ingin bekerja untuk mempertaruhkan keselamatan.

\section{Sikap Tenaga Kerja pada Penerapan Rapi di bagian Produksi PT. Maritim Barito Perkasa}

Hasil dari Tabel 3 telah digambarkan bahwa kebanyakan tenaga kerja bersikap pada pernyataan mempertahankan agar kondisi barang dan alat bersih dan tidak rusak sebanyak 13 orang. Ini membuktikan bahwa sebagian besar tenaga kerja pada bagian produksi PT. Maritim Barito Perkasa selalu merawat barang dan alat sehabis pemakaian setiap harinya. 
Tetapi masih ada 7 orang yang langsung menyimpan alat kerja tanpa mengecek dan membersihkan digambarkan bahwa kebanyakan tenaga kerja mempunyai sikap pada pernyataan menyimpan barang ke tempat penyimpanan sebanyak 10 orang. Dengan tenaga kerja hanya menyimpan barang dan alat kerja tanpa merapikan barang dan alat tersebut, itu bisa membuat barang dan alat menjadi cepat rusak dan untuk menjangkau peralatan yang akan digunakan lagi membutuhkan waktu untuk mencari alat tersebut. 9 orang tenaga kerja memilih jawaban yang benar yaitu berusaha selalu merapikan dan menyimpan barang dan alat ke tempat penyimpanan. Dan 1 orang lainnya lebih memilih acuh dan tidak melakukan apa-apa untuk barang dan alat yang berada di area kerja. Menurut Jahja (2009), tempat kerja yang rapi merupakan cermin pribadi bagaimana penghuni tempat kerja. Jika tenaga kerja merasakan tempat yang nyaman dan rapi produktivitas juga akan ikut meningkat dengan tajam. Tenaga kerja juga terpacu untuk menjadi lebih semangat dalam bekerja.

Efisiensi memang sangat dibutuhkan pada era globalisasi ini untuk bersaing dengan berbagai perusahaan Sebaiknya memang perlu adanya pelabelan untuk rak dan barang agar alat dan barang tidak mudah rusak. Sesuai dengan Peraturan Menteri Perburuhan No. \& Tahun 1964 di tempat kerja alat dan bahan harus disusun dan disimpan secara rapi dan tertib sehingga tidak menimbulkan bahaya tertimpa atau menyebabkan tenaga kerja terjatuh.

Area kerja yang rapi, risiko kehilangan barang dan alat kerja akan berkurang. Setiap barang dan alat yang hilang ditempatnya dapat segera ditemukan dan dikenali, risiko kehilangan dan waktu untuk mencari barang atau alat yang hilang dapat dicegah. Sesuai dengan prinsip utama tempat kerja yang rapi yaitu: "Setiap barang yang berada di tempat kerja mempunyai tempat yang pasti (Jahja 2009).

\section{Sikap Tenaga Kerja pada Penerapan Resik di bagian Produksi PT. Maritim Barito Perkasa}

Keadaan tempat kerja yang kotor, sampah yang berserakan. Debu, keadaan dinding, atap, dan ventilasi yang kurang baik dapat membuat menurunnya produktivitas kerja dari para pekerja. Dan yang lebih membahayakan lagi bila terjadi kecelakaan kerja dan penyakit akibat kerja, karena bukan hanya para pekerja yang terkena dampak kerugian tetapi perusahaan juga ikut terkena dampak seperti waktu biaya produksi. Perubahan sedikit pada lingkungan kerja dapat membuat peningkatan yang besar yang berdampak bagi para pekerja yaitu efisiensi, kualitas, produktivitas dan keselamatan kerja.

Sesuai dengan Peraturan Menteri Perburuhan No. 7 Tahun 1964 bahwa di tempat kerja sampah harus terkumpul pada tempat yang rapi dan tertutup serta lantai, dinding, loteng dan atap harus selalu dalam keadaan bersih dan terpelihara agar tenaga kerja yang berada di area kerja tidak terganggu dan merasa nyaman untuk bekerja

Kebiasaan tenaga kerja terhadap resik sudah baik terbukti dengan 16 orang atau $80 \%$ langsung membersihkan kotoran yang ada di tempat kerja. Padahal dalam kenyataannya belum terbagi menjadi kelompok-kelompok kerja yang mempunyai tugas dan tanggung jawab terhadap area kerja dan jadwal piket. Tetapi, kesadaran dari tenaga kerja tentang pentingnya suasana bersih yang membuat tenaga kerja tidak perlu perintah untuk membersihkan area kerja. 3 orang lainnya lebih memilih menunggu petugas kebersihan dan 1 orang lainnya lebih memilih acuh dan tidak melakukan apa-apa.

Membersihkan adalah salah satu dasar peting aktivitas 5R dan bukan merupakan gagasan baru. Tetapi tidak kalah penting walaupun bukan merupakan sesuatu yang baru (Osada, 2011).

\section{Sikap Tenaga Kerja pada Penerapan Rawat di bagian Produksi PT. Maritim Barito Perkasa}

Hasil dari Tabel 5 telah digambarkan bahwa kebanyakan tenaga kerja mempunyai sikap pada pernyataan mempertahankan agar kondisi barang dan alat bersih dan tidak rusak sebanyak 13 orang. Ini membuktikan bahwa sebagian besar tenaga kerja pada bagian produksi PT. Maritim Barito Perkasa selalu merawat barang dan alat sehabis pemakaian setiap harinya. Tetapi masih ada 7 orang yang langsung menyimpan alat kerja tanpa mengecek dan membersihkan.

Menurut Pangestiaji (2010), Rawat adalah mengusahakan agar tempat kerja yang sudah baik dapat selalu terpelihara. Di area kerja yang aman dan terawat, bahaya dan penyimpangan dapat langsung dikenali sedini mungkin contoh peminjaman barang yang tak dikembalikan ke tempat semula dan perlakuan yang salah terhadap barang sehingga menjadi cacat.

Perlu adanya penyuluhan dari pimpinan unit untuk menyadarkan kepada tenaga kerja untuk selalu merawat alat dan barang agar tidak mudah rusak. Karena jika barang dan alat mudah rusak maka biaya yang dikeluarkan oleh perusahaan akan semakin bertambah. 


\section{Sikap Tenaga Kerja pada Penerapan Rajin di bagian Produksi PT. Maritim Barito Perkasa}

Hasil dari Tabel 6 telah digambarkan bahwa kebanyakan tenaga kerja mempunyai sikap selalu datang tepat waktu yaitu pukul 08.00 WITA dengan jumlah orang 18 atau $90 \%$. Ini membuktikan bahwa hampir semua tenaga kerja patuh terhadap peraturan yang ada. Meskipun ada 2 orang yang menjawab kadang-kadang untuk penerapan ini. Ini sebagai langkah awal bagaimana tenaga kerja nantinya taat pada peraturan yang tertulis dan yang tidak tertulis. Dari hal-hal yang kecil bisa membuktikan bagaimana tenaga kerja berproses pada saat di area kerja apakah baik ataukah bisa sebaliknya yaitu buruk.

Rajin ditambahkan sebagai penutup dari 5R guna mengingatkan kembali tentang pentingnya unsur manusia dalam penerapan dan memberi arah bagaimana manusia dapat memenuhi perannya sebagai manusia seutuhnya (Jahja, 2009).

Sikap yang rajin secara terus menerus akan mendukung keadaan tempat kerja yang nyaman. Sikap tersebut mendukung juga dari segi efisiensi dan produktivitas kerja karena dalam penerapannya, hubungan antara tenaga kerja dan atasan menjadi lebih dekat dan area kerja menjadi nyaman. (Jahja, 2009).

\section{SIMPULAN}

Kebijakan penerapan $5 \mathrm{R}$ oleh pimpinan perusahaan di PT. Maritim Barito Perkasa masih belum tertulis. Itu menandakan masih belum adanya dukungan secara penuh untuk penerapan $5 \mathrm{R}$ sehingga pelaksanaannya juga tidak bisa berjalan dengan maksimal. Belum adanya pembentukan tim audit dan pengurus $5 \mathrm{R}$ guna penerapan sekaligus evaluasi yang baik pada PT. Maritim Barito Perkasa.

Tingkat pengetahuan tentang penerapan $5 \mathrm{R}$ dari tenaga kerja PT. Maritim Barito Perkasa bagian produksi sebagian besar adalah baik. Ini dibuktikan dengan pengisian kuesioner oleh tenaga kerja bagian produksi.

Untuk pemahaman dan sikap tenaga kerja dengan penerapan $5 R$ juga sudah baik. Hanya dalam penerapan rapi belum semuanya sepakat. Masih ada yang langsung menyimpan alat dan barang kerja tanpa penataan yang baik. Untuk penerapan Ringkas, Resik, Rawat dan Rajin sudah baik secara sikap dan pelaksanaannya. Dukungan yang penuh antar sesama pihak baik pimpinan maupun tenaga kerja harus terjadi karena dengan sama-sama ikut mendukung berarti penerapan $5 \mathrm{R}$ juga akan berjalan dengan sustainable dan maksimal.

\section{DAFTAR PUSTAKA}

Depnaker. RI. 1964. Peraturan Menteri Perburuhan No. 7 Tahun 1964 tentang Syarat-syarat Kesehatan, Kebersihan, Serta Penerangan di Tempat Kerja, Jakarta.

Depnaker. RI. 1970. Undang-undang No. 1 Tahun 1970 tentang Keselamatan Kerja, Jakarta.

Fitriyah, E. 2009. Penerapan 5R sebagai Salah Satu Upaya Pencegahan Kecelakaan Kerja Bagian Produksi unit III CV. Setia Kawan Tulungagung. Tugas akhir. Surabaya: Universitas Airlangga

Hirano, H. 1995. Penerapan 5R di Tempat Kerja. Jakarta: PQM Consultans.

Jahja, K. 2009. 5R (Ringkas, Rapi, Resik, Rawat, Rajin) Dasar Membangun Industri Kelas Dunia, Jakarta Pusat; PT. Temprint.

Jamsostek. 2012. Laporan Tahunan Tahun 2011. Jakarta: Jamsostek.

Jamsostek. 2013. Laporan Tahunan Tahun 2012. Jakarta: Jamsostek.

Jamsostek. 2014. Laporan Tahunan Tahun 2013. Jakarta: Jamsostek.

Notoatmodjo, S. 2012. Metodologi Penelitian Kesehatan. Jakarta: Rhineka Cipta.

Osada, T. 2011. Sikap Kerja 5S. Jakarta; PPM.

Pangestiaji, R. 2010. Penerapan Ringkas, Rapi, Resik, Rawat, Rajin (5R) di Bagian Produksi dan di Bagian Administrasi PT. Semen Gresik (Persero) Tbk. Pabrik Tuban. Skripsi. Surabaya: Universitas Airlangga.

Setyanto, G.E. 2015. Analisis Penerapan 5R pada Bagian Produksi di PT. Maritim Barito Perkasa. Skripsi. Surabaya: Universitas Airlangga.

Sinjangga, A. 2009. Budaya Perusahaan. Tanggal sitasi: 3 Juli 2010.

Sukmawati, R. 2005. Pelaksanaan 5R di Balai Pengobatan PT. Kertas Leces. Tugas Akhir. Surabaya: Universitas Airlangga.

Sutjana, I.D.P. 2006. Hambatan Dalam Penerapan K3 dan Ergonomi di Perusahaan. Disampaikan pada Seminar Ergonomi Dan K3 29 Juli 2006 di Surabaya. Tanggal sitasi: 29 April 2008.

Suma'mur. PK. 1997. Keselamatan Kerja dan Pencegahan Kecelakaan. Jakarta; PT. Gunung Agung. 